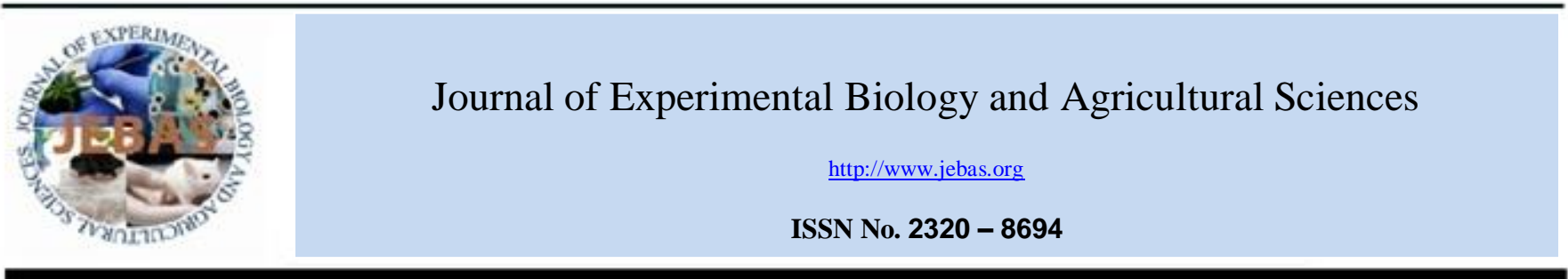

\title{
PERSPECTIVES OF SAUDIS AND NON-SAUDIS ON WATER ISSUES IN THE RURAL AREAS OF THE KINGDOM OF SAUDI ARABIA
}

\author{
Fahad O. Aldosari*, Khodran Hamdan Al-Zahrani, Abdullah A. Al-Zaidi, Mirza B. Baig, Siddig El \\ Tayeb Muneer, Muhammad Muddassir, Muhammad Mubushar
}

Department of Agricultural Extension and Rural Society

College of Food and Agriculture Sciences

King Saud University,

P.O. Box 2460, Riyadh 11451,

Kingdom of Saudi Arabia.

Received - March 27, 2017; Revision - May 16, 2017; Accepted - May 21, 2017

Available Online - August 31, 2017

DOI: http://dx.doi.org/10.18006/2017.5(Spl-1-SAFSAW).S86.S90

\section{KEYWORDS}

Irrigation Technologies

Water-Use-Efficiency

Reduce Waste

Enhanced Production

Extension Education

\begin{abstract}
The discovery of oil in the Kingdom of Saudi Arabia (KSA) opened many new avenues for the expatriates including in the area of agriculture and farming. The foreign workers also got into the farming business in the Kingdom. Water is an important input to practice agriculture. However, no comparative information is available regarding the attitude of Saudis and non-Saudis towards water. Keeping in view the importance of water, present study was conducted in the 13 administrative regions of the country. Using the Random Number Generator, some 230 respondents were selected randomly from each region with the total sample size was of 3000 . Some 1800 respondents completely filled the study questionnaire. The study was aimed to examine and provide information regarding comparative perceptions of Saudis and Non-Saudis regarding some issues related to irrigation water; a topic that has not been studied so far. According to study findings, the Non-Saudis farmers have higher awareness about water uses and modern irrigation systems. Significant differences regarding their knowledge on the importance of irrigation water resources, the potential benefits of modern irrigation methods and awareness on the problems faced by farmers regarding water quality in the Kingdom of Saudi Arabia were noticed. The study suggests the launching of extension education programs for both the Saudis and Non-Saudis farmers to keep them informed with the latest farming technologies and elevate their technical knowledge.
\end{abstract}

* Corresponding author

E-mail: fadosri@kus.edu.sa (Fahad O. Aldosari)

Peer review under responsibility of Journal of Experimental Biology and Agricultural Sciences.

Production and Hosting by Horizon Publisher India [HPI] (http://www.horizonpublisherindia.in/).

All rights reserved.
All the article published by Journal of Experimental Biology and Agricultural Sciences is licensed under a Creative Commons Attribution-NonCommercial 4.0 International License Based on a work at www.jebas.org.

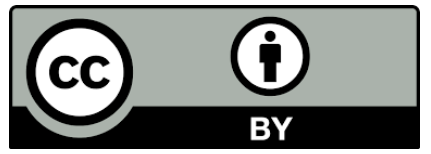




\section{Introduction}

With more than half its desert landscape, occupying almost 80 percent of the Arabian Peninsula, the Kingdom of Saudi Arabia, covers a landmass of over 2,150,000 square kilometers $(830,000$ square miles). Located in the southwest corner of Asia, the Kingdom is at the crossroads of Europe, Asia and Africa. It is surrounded by the Red Sea on the West with its coastline stretching about 1,760 kilometers (1,100 miles) while the Arabian Gulf coastline roughly covers 560 kilometers ( 350 miles) in the East (Saudi Geological Survey, 2012). From May to October, the Kingdom of Saudi Arabia experiences hot weather and it is dry cold in the winter. During the last four decades, the population is increasing at the annual growth rate of $3.4 \%$ and it has gone up from 7 to 27 million today (CDSI, 2012). High population growth rate poses severe strain and stress on the water resources of the Kingdom. On the other hand, the Kingdom also witnessed remarkable economic development, rising living standards and alarming urbanization due to the huge oil revenues. Due to the impressive economic development, the advanced irrigation technologies were made available to the farmers, abundant water water supplies became available to the consumers including the farmers. Also increased supplies brought more area under cultivation to enhance agricultural production. Similarly the water consumption also went high in the municipal facilities and manufacturing industries due to easy and abundant water supplies (FAO, 2009). However, the higher rates of withdrawal of water from non-renewable qualifiers than the rates of recharge severely damaged the limited water resources of the Kingdom (Al-Zahrani, 2010; Al-Zahrani \& Baig, 2011; Al-Zahrai etal., 2016).

UNESCO also reports that the Kingdom faces extreme water shortage because of the desert environment and scanty average rainfall of less than $100 \mathrm{~mm}$ per year (World Bank, 2004; Abderrahman, 2006; Al-Zahrani, 2010; Al-Zahrani \& Baig, 2011; CDSI, 2012; Al-Zahrai et al., 2016).

The Kingdom enjoys no self-renewal course of surface water. Intermittent flash floods (Wadis) are the only existing source of surface water. However, runoff quantity and duration widely changes with the distribution and pattern of rainfall. It was estimated that due to intermittent flash floods about 0.6 Billion $\mathrm{m}^{3}$ water is being captured in 260 irrigation dams per year and is resultantly used for farming (Al-Zahrani \& Baig, 2011; Ministry of Water and Electricity, 2012). The groundwater system, consisting of both the renewable and non-renewable aquifers happens to be the only source of natural potable water in the Kingdom. The non-renewable underground layer of the water extends out from the northern boundary southwards into the Empty Quarter, and eastwards from the central area to the Arabian Gulf (World Bank, 2005). The total dissolved solids (TDS) present in the aquifer's water range from 300 to more than 10,000 parts per million (Ministry of Water and Electricity, 2012). The renewable groundwater resources prevail in the Western and Southwestern part of the Kingdom (World Bank, 2005). The potable water is also obtained by desalination. The water production from the desalination plants increased from about 200 million $\mathrm{m}^{3} /$ year in 1980 to 1050 million $\mathrm{m}^{3} / \mathrm{year}$ in 2010 (Saline Water Conservation Corporation, 2010; Al-Zahrani \& Baig, 2011; Ministry of Water and Electricity, 2012). In 2014, the KSA government planned to further increase the production capacity of desalination plants about 2.07 billion $\mathrm{m}^{3} /$ year, making the Kingdom the largest producer of desalinated water in the world (Ministry of Economy and Planning, 2010).

Treated wastewater has been a source of water being used in landscaping and irrigating the agricultural crops in the Kingdom. In 2010 , about 240 million $\mathrm{m}^{3} /$ year of the treated wastewater was used across the country at the national level, accounting for about $12 \%$ domestic water consumption and $34 \%$ of the generated treated wastewater (Ministry of Water and Electricity, 2012). Though the Kingdom of Saudi Arabia faces the severe shortage of water still the large numbers of foreign workers got themselves engaged into the farming business. In the situation, drought management, climate change and the availability of water have become issues of prime importance in the Kingdom (Sauri et al., 2013). The scientists believe that utilization of water in agriculture judiciously (especially in arid environment) results sustainable crop production and that in turn helps ensuring food security (AlZahrani \& Baig, 2011). Despite of this belief, the perceptions of the Saudis and non-Saudis agricultural producers regarding the use of irrigation waters have not been studied so far. The situation prompted the researchers to assess the respondents' perceptions on the use of irrigation waters and determine the understanding of the respondents on the usefulness and the associated benefits of using modern irrigation methods in the Kingdom of Saudi Arabia. Furthermore, the farmers' behavior towards water uses may consolidate efficacy of water uses during drought span and will help the policy-makers in designing water related projects.

\section{Materials and Methods}

The study was conducted in the major agricultural 13 administrative regions of the Kingdom of Saudi Arabia. To establish the study sampling-frame, a list of the farms located in all the governorates of the Kingdom of Saudi Arabia was obtained from the Ministry of Agriculture. To establish the study sample, a random sample was drawn by using the Random Number Generator and 230 respondents were selected from each region with the total sample size of 3000 . Finally about 1800 farms participated in the survey. The data were collected by conducting personal interviews of the farmers against the well-structured questionnaire. Before launching the study, the questionnaire was tested on the 20 farmers who were not part of the study. Necessary modifications on the questionnaire were made with the help of the faculty members specializing in irrigation and social sciences from the Departments of Agricultural Extension and Rural Society, Agricultural Engineering and Plant Production, College of Food and Agriculture Sciences, King Saud University, Saudi Arabia. The questionnaire was further validated for its internal consistency. Data collected against the questionnaire were decoded, tabulated and further subjected to statistical analyses by using the SPSS program. 


\section{Results and Discussion}

The statement "Groundwater is a non-renewable resource in the Kingdom" with the mean difference value (.09864) shows highly significant difference $\left(.000^{* *}\right)$ as revealed in the Table -1 . The study also indicated that non-Saudis attached greater importance to the groundwater and considers it a non-renewable resource in the Kingdom. The mean difference of (.14840) revealed a significant relationship $\left(.029^{* *}\right)$ with statement "The scarcity of quality irrigation water is the most prominent problem faced by agriculture in the world". The survey clearly revealed that nonSaudis farming communities were well-aware of the water issue in the Kingdom of Saudi Arabia. The possible reason could be that the foreign workers have had greater opportunities to meet with each other and were having more leisure times to have discussions with the immigrants (coming from the same origin) on farming issues of their mutual interests. The results also depicted that with the mean difference of (.59026), a highly significant difference $\left(.000^{* *}\right)$ for the statement "The rate of withdrawal of water from various water sources in the Kingdom is higher than its recharge" was realized, indicating that the non-Saudis were well aware of the withdrawal of water from various water sources in the Kingdom was higher than its recharge. High awareness on the use of water by the non-Saudis could be due to their greater interest and concern over the water issue because it affects their farming activities.

With the mean difference (.03746), a highly significant difference $\left(0.010^{* *}\right)$ for the statement "Modern irrigation systems reduce waste land (uncultivated)" was realized as depicted in Table - 2. While the statement "Modern irrigation systems reduce wastage of water" showed a highly significant difference $(.001 * *)$ with a mean difference of (.25799).

The study revealed that non-Saudi farming communities were significantly more knowledgeable on the potential role and capability of modern irrigation methods in reducing wastelands than Saudi farmers. They might have learned through their experiences that by using modern irrigation systems like drip irrigation more areas could be brought under cultivation by reducing wastelands.

"Irrigation spray protects crops from heat damage" depicted a significant difference $\left(.036^{* *}\right)$ with a mean difference of (.11597). It also revealed that non-Saudis had greater awareness on the effect of irrigation spray on crop protection. It might be result of greater involvement of non-Saudis in the farming as a labor or farm managers and they might have learned it through their experiences.

\section{Conclusions and recommendations}

The development realized due to oil-based economy resulted a continued influx of expatriates in the Kingdom, making them engaged in all quarters including farming and agricultural business. The Kingdom of Saudi Arabia is a water deficient country due to its harsh climatic conditions i.e. high temperatures, cloudless skies and less number of water aquifers. Previously the focus of agricultural extension has been only on Saudi farming communities to equip them with the latest farming technologies and information. This study is intended to assess levels of knowledge of Saudis and Non-Saudis regarding water scarcity, and examine their behaviors regarding the use of irrigation water. The study revealed that the Non-Saudis farmers had greater awareness on the issue of water shortage at the global level. Also, their awareness levels on the use of irrigation water were significantly higher than the Saudi farmers. Non-Saudi farmers also had better understanding of the potential benefits of modern irrigation methods. According to the results of the study, the NonSaudi farmers had greater awareness on the water uses. The study indicated the significant differences between the Saudi and nonSaudi farmers regarding their knowledge on the importance of

Table 1 Irrigation water and its sustainable use from the view point of the Saudis and non-Saudis

Variables Mean for Mean for Mean Difference F-value
Saudis Non-Saudis

\begin{tabular}{|c|c|c|c|c|c|}
\hline Agriculture relies heavily on groundwater & 4.1022 & 3.3250 & -.77724 & .209 & .648 \\
\hline $\begin{array}{l}\text { Groundwater is a non-renewable resource in } \\
\text { the Kingdom }\end{array}$ & 3.7764 & 3.8750 & .09864 & 13.450 & $.000 * *$ \\
\hline $\begin{array}{l}\text { The ground water in most of the regions } \\
\text { contains high salts }\end{array}$ & 3.9265 & 3.7250 & -.20152 & .012 & .914 \\
\hline $\begin{array}{l}\text { Saline irrigation water in large quantities leads } \\
\text { to the deterioration of soils }\end{array}$ & 4.0990 & 4.2000 & .10096 & 1.426 & .233 \\
\hline $\begin{array}{l}\text { The scarcity of quality irrigation water is the } \\
\text { most prominent problem faced by the } \\
\text { agriculture in the world }\end{array}$ & 4.5016 & 4.6500 & .14840 & 4.821 & $.029 * *$ \\
\hline $\begin{array}{l}\text { The rate of withdrawal from various water } \\
\text { sources in the Kingdom is higher than its } \\
\text { recharge }\end{array}$ & 4.1597 & 4.7500 & .59026 & 13.503 & $.000 * *$ \\
\hline
\end{tabular}

*Significant at 0.05 and $* *$ Significant at 0.01 
Table: 2 Effect of modern irrigation systems on farms and the farming

\begin{tabular}{|c|c|c|c|c|c|}
\hline Variables & $\begin{array}{l}\text { Mean for } \\
\text { Saudis }\end{array}$ & $\begin{array}{c}\text { Mean for } \\
\text { Non- } \\
\text { Saudis }\end{array}$ & $\begin{array}{c}\text { Mean } \\
\text { Difference }\end{array}$ & F- value & Sig \\
\hline $\begin{array}{l}\text { Modern irrigation systems ensure uniform distribution of water } \\
\text { according to the need of each crop }\end{array}$ & 3.4345 & 3.4250 & -.00950 & .475 & .491 \\
\hline Modern irrigation systems reduce waste land (uncultivated) & 3.2875 & 3.3250 & .03746 & 6.656 & $.010 * *$ \\
\hline Modern irrigation systems reduce the wastage of water & 3.4920 & 3.7500 & .25799 & 12.318 & $.001 * *$ \\
\hline $\begin{array}{l}\text { Modern irrigation systems enhance germination rate and crop } \\
\text { productivity }\end{array}$ & 3.1981 & 3.3500 & .15192 & 1.352 & .246 \\
\hline Modern irrigation systems reduce salinity hazard in the soil & 2.9105 & 3.3500 & .43946 & 1.934 & .165 \\
\hline $\begin{array}{l}\text { Modern irrigation systems facilitate the application of fertilizers } \\
\text { and pesticides with water }\end{array}$ & 3.0447 & 3.3000 & .25527 & .698 & .404 \\
\hline Irrigation spray protects crops from heat damage & 2.9840 & 3.1000 & .11597 & 4.416 & $.036 * *$ \\
\hline The use of modern irrigation systems maintain soil porosity & 3.4952 & 3.5385 & .04325 & .664 & .416 \\
\hline Modern irrigation systems reduce spreading of weeds on the farm & 3.0351 & 3.1750 & .13986 & 1.198 & .275 \\
\hline \multirow[t]{2}{*}{$\begin{array}{l}\text { Modern irrigation systems reduce the spread of diseases and } \\
\text { insects on the farms }\end{array}$} & 3.0767 & 3.0750 & -.00168 & 2.470 & .117 \\
\hline & 3.0096 & 3.4000 & .39042 & .569 & .451 \\
\hline
\end{tabular}

$*$ Significant at 0.05 and $* *$ Significant at 0.01

irrigation water resources, the potential benefits of modern irrigation methods and also awareness on the problem faced by farmers regarding water quality in the Kingdom of Saudi Arabia. From the results of study, it is concluded that farmers know the importance of sustainable use of water and its role in realizing sustainable agriculture and that in turn helps ensuring food security.

It is recommended that concerted efforts are needed to launch extension education programs especially on the wise and judicious use of water and its related issues to create awareness among both the Saudis and non-Saudi farmers. More farms owned by the more knowledgeable non-Saudi farmers are to be used as class-rooms to educate the Saudi farmers on the judicious of water and water saving farming technologies. It is also recommended that National Agricultural Extension Service of Saudi Arabia takes measures to bring the farming communities of all the 13 regions closer to bridge up the knowledge gaps and share their experiences. It is well-established that the farmers feel comfortable in learning about the innovations from their fellow farmers.

\section{Acknowledgments}

The authors are extremely thankful to the Deanship of Scientific Research, and Research Center at College of Food and Agriculture Sciences, King Saud University for supporting the research work.

\section{Conflict of interest}

Authors would hereby like to declare that there is no conflict of interests that could possibly arise.

\section{References}

Abderrahman WA (2006) Groundwater Resources Management in Saudi Arabia. Special Presentation and Water Conservation Workshop, Al Khobar, Saudi Arabia, December 2006.

Al-Zahrani KH, Baig MB (2011) Water in the Kingdom of Saudi Arabia: Sustainable Management Options. The Journal of Animal \& Plant Sciences 21: 601-604.

Al-Zahrani KH (2010) Water Demand Management in the Kingdom of Saudi Arabia. Conference of International Journal of Art \& Science 2: 68-76.

Al-Zahrani KH, Muneer SE, Taha AS, Baig MB (2016) Enhancing irrigation efficiency in Saudi Arabia. In: Goyal MR, Chavan VK, Tripathi VK (Eds.) Innovations in Micro Irrigation Technology: Research advances in Micro-Irrigation, CRC Group USA (Taylor \& Francis Group) and Apple Academic Press Inc., Canada Pp. 315-334.

CDSI (2012) Population \& Housing Census for 1431 A.H (2010 A.D). Saudi Central Department of Statistics \& Information. 
Findings", available online at: http://www.cdsi.gov.sa/, 2010 access on 29th April, 2011.

FAO (2009) Food and Agriculture Organization of the United Nation "Saudi Arabia. Irrigation in the Middle East regions in figures. Aquatat Survey -2008”, FAO Land and Water Division Report 34, PP 325-337, edited by Karen Freken, 2009.

Ministry of Economy and Planning (2010) "the Nine Development Plan 2010-2014" Ministry of Economy and Planning Documents, Riyadh, KSA, 2010.

Ministry of Water and Electricity (2012) Supporting Documents for King Hassan II Great Water Prize”, 2012.

Saline Water Conservation Corporation (2010) Annual Report for
Operation \& Maintenance", Saline Water Conservation Corporation, Pp. 20-35, 2010.

Saudi Geological Survey (2012) Kingdom of Saudi Arabia Numbers and Facts, First Edition, Available online at: www.sgs.org.sa, 2012. Accessed on November 30th, 2012.

Sauri D (2013) Water conservation. Theory and evidence from the urban areas of the developed world. Annual Review of Environment and Resources 38: 1-22.

World Bank (2005) A Water Sector Assessment Report on Countries of the Cooperation Council of the Arab State of the Gulf', Report No. 32539-MNA, March 31, 2005.

World Bank (2004) Kingdom of Saudi Arabia, Assessment of the Current Water Resource Management Situation. Phase IVolume 1, Main Report, April 2004. 